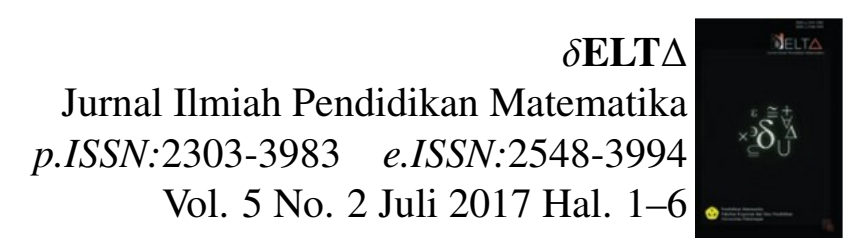

\title{
EFEKTIVITAS MODEL PEMBELAJARAN MMP DIPADU DENGAN STRATEGI SSCS TERHADAP KEMAMPUAN PEMECAHAN MASALAH SISWA MATERI KUBUS DAN BALOK SMP NEGERI 5 BATANG
}

\author{
Millatus Saniyah $^{\mathrm{a}}$ \\ ${ }^{a}$ Pendidikan Matematika FKIP Universitas Pekalongan, millatussaniyah@gmail.com
}

\begin{abstract}
This study aims to determine the effectiveness of the MMP learning model combined with the SSCS Strategy on Students' Problem Solving Ability of Cube and Cuboid materials. This research is an experimental quantitative research with quasi experimental research design of the nonequivalent posttest-only control group design. In this study, the population is all of the 8th grade students of SMP Negeri 5 Batang in the academic year of 2016/2017. By using cluster random sampling technique, 2 classes were chosen as sample class. Class VIII A as the experimental class with MMP learning model combined with SSCS strategy and class VIII D as the control class with expository learning strategy. Variables in this research is MMP learning model combined with SSCS strategy (independent variable) and problem solving ability (dependent variable). Documentation and test method are used to obtain the data. The data was analyzed by using classical exhaustiveness test and average difference test.

The results showed: (1) $z_{\text {score }}(1.85) \geq z_{\text {table }}(1.64)$ which means the students ability of experimental class in solving problems can achieve completeness; and (2) $t_{\text {score }}(3.19)>t_{\text {table }}(1.67)$ which means the problem solving ability of students of experimental class is better than the control class. Based on these two results, it can be concluded that the application of MMP learning model combined with SSCS Strategy achieves effective criteria for problem solving ability.
\end{abstract}

Keywords: MMP, SSCS, kemampuan pemecahan masalah

\section{Pendahuluan}

Pendidikan adalah pengalaman-pengalaman belajar terprogram sebagai salah satu bentuk upaya untuk meningkatkan kualitas sumber daya manusia agar di kemudian hari dapat memainkan peranan hidup yang tepat [1, hal. 5]. Pendidikan yang baik dapat diupayakan melalui perbaikan mutu dalam pendidikan yaitu dengan cara meningkatkan kualitas proses pembelajaran pada semua mata pelajaran, termasuk pada mata pelajaran matematika. Kemampuan pemecahan masalah menjadi salah satu fokus dalam pembelajaran matematika yang penting untuk dikembangkan. Hal ini sesuai dengan salah satu tujuan pembelajaran matematika yang termuat dalam Permendiknas No. 22 Tahun 2006 yaitu agar siswa memiliki kemampuan memecahkan masalah yang meliputi kemampuan memahami masalah, merancang model matematika, menyelesaikan model, dan menafsirkan solusi yang diperoleh [2, hal. 346].

Berdasarkan wawancara dengan salah satu guru matematika kelas VIII di SMP N 5 Batang, pemecahan masalah merupakan kegiatan yang masih dianggap sulit baik bagi siswa maupun bagi guru dalam proses belajar mengajarnya. Kesulitan yang dialami siswa dalam memecahkan masalah matematika salah satunya yaitu pada materi bangun ruang sisi datar jenis kubus dan balok, tepatnya ketika siswa dihadapkan dengan soal yang berbentuk cerita. 
Kemampuan pemecahan masalah siswa dapat dilatih dan dikembangkan melalui proses pembelajaran yang dikemas sedemikian rupa dengan memanfaatkan segala potensi yang dimiliki oleh siswa. Di samping itu, siswa perlu dilibatkan secara aktif dalam proses pembelajaran yaitu dengan mengkonstruksi pengetahuannya sendiri. Oleh karena itu, guru harus lebih selektif dalam menentukan model ataupun strategi mengajar yang tepat dan sesuai agar siswa dapat belajar dengan baik sehingga pembelajaran dapat berlangsung secara efektif dan efisien dan dapat mencapai tujuan pembelajaran yang diharapkan.

Jenis model dan strategi pembelajaran yang tepat untuk dipadukan guna meningkatkan kemampuan pemecahan masalah siswa adalah model pembelajaran MMP (Missouri Mathematic Project) dan strategi pembelajaran SSCS (Search Solve Create Share). Menurut Widdiharto (dalam [3, hal. 99]), model MMP memuat langkah-langkah: (1) review, (2) pengembangan, (3) latihan terkontrol, (4) kerja mandiri, (5) penugasan. Sedangkan menurut Pizzini (dalam [4, hal. 3]), pembelajaran SSCS merupakan salah satu pembelajaran yang terpusat pada siswa, yang melibatkan siswa dalam setiap fasenya yaitu: fase Search Solve Create Share.

Adapun urutan perpaduan fase yang dilalui dalam pembelajaran menggunakan model MMP yang dipadu dengan strategi SSCS yaitu: (1) fase Review dipadukan dengan fase Share; (2) fase Pengembangan dipadukan dengan fase Search; (3) fase Latihan terkontrol/kerja kooperatif dipadukan dengan fase Search, Solve, Create dan Share; (4) fase Seatwork/kerja mandiri dipadukan dengan fase Search, Solve dan Create; dan (5) fase Penugasan dipadukan dengan fase Search, Solve, dan Create.

Melalui penerapan model MMP yang dipadu dengan strategi SSCS ini, siswa diberikan kesempatan untuk mempraktekkan dan mengasah kemampuan pemecahan masalah matematika baik secara individu maupun secara berkelompok. Selain itu juga diberikan kesempatan untuk mempelajari dan memantapkan konsep-konsep dengan cara yang lebih bermakna, mengolah informasi, menggunakan keterampilan berpikir tingkat tinggi, serta bekerjasama dengan orang lain, sehingga siswa dapat terlatih dalam memahami masalah, mengkonstruksi atau menyusun suatu permasalahan yang disajikan dan menemukan suatu strategi untuk memecahkan masalah matematika. Dengan demikian, penerapan model MMP yang dipadu dengan strategi SSCS dalam proses pembelajaran di sekolah lebih efektif untuk mengembangkan kemampuan pemecahan masalah matematika siswa dibandingkan dengan strategi pembelajaran ekspositori.

Berdasarkan latar belakang masalah yang telah dijelaskan, maka tujuan penelitian ini adalah untuk mengetahui keefektifan model pembelajaran MMP dipadu dengan strategi SSCS terhadap kemampuan pemecahan masalah siswa materi Kubus dan Balok.

\section{Metodologi Penelitian}

Jenis penelitian yang dilaksanakan adalah penelitian kuantitatif eksperimental dengan desain penelitian berupa quasi eksperimental bentuk the nonequivalent posttest-only control group design yang dapat dilihat pada Tabel 1 berikut [5, hal. 136].

Tabel 1. Rancangan Desain Eksperimen

\begin{tabular}{ccc}
\hline Kelompok & Perlakuan & Post test \\
\hline Eksperimen & $\mathrm{X}$ & $\mathrm{O}$ \\
Kontrol & - & $\mathrm{O}$ \\
\hline
\end{tabular}

Populasi dalam penelitian ini adalah seluruh siswa kelas VIII SMP Negeri 5 Batang tahun pelajaran 2016/2017. Pemilihan kelas sebagai kelas sampel dilakukan dengan menggunakan teknik cluster random sampling/acak kelas [5, hal. 138]. Melalui teknik cluster random sampling terpilih 2 kelas sampel yaitu kelas VIII A sebagai kelas eksperimen dengan model pembelajaran MMP dipadu dengan strategi SSCS dan kelas VIII D sebagai kelas kontrol dengan 
strategi pembelajaran ekspositori. Variabel bebas dalam penelitian ini adalah model pembelajaran MMP dipadu dengan strategi SSCS, sedangkan variabel terikatnya adalah kemampuan pemecahan masalah.

Adapun rancangan kegiatan dalam penelitian ini adalah: (1) melakukan wawancara dengan salah satu guru matematika kelas VIII di SMP Negeri 5 Batang; (2) menentukan populasi penelitian; (3) memilih dua kelas sampel dari populasi yang telah ditentukan; (4) memilih kelas uji coba; (5) mengambil data nilai kompetensi pengetahuan matematika kedua kelas sampel sebagai data awal penelitian; (7) menyusun instrumen tes kemampuan pemecahan masalah; (8) melaksanakan pembelajaran pada kelas eksperimen dan kontrol; (9) melakukan uji coba instrumen tes kemampuan pemecahan masalah pada kelas uji coba; (10) menganalisis hasil tes uji coba instrumen; (11) menentukan butir soal yang bisa digunakan untuk posttest kemampuan pemecahan masalah pada kedua kelas sampel; (12) melaksanakan post test untuk mengetahui kemampuan pemecahan masalah siswa kelas eksperimen dan kelas kontrol; (13) menganalisis data hasil post test kemampuan pemecahan masalah; (14) menyusun laporan penelitian.

Metode yang digunakan untuk memperoleh data yaitu metode dokumentasi dan tes. Metode dokumentasi digunakan untuk mendapatkan data mengenai nama dan jumlah siswa yang menjadi anggota populasi, untuk menentukan anggota sampel dan untuk memperoleh foto-foto serta daftar nilai kompetensi pengetahuan matematika siswa yang menjadi sampel penelitian. Metode tes digunakan untuk memperoleh data tentang kemampuan pemecahan masalah siswa pada materi kubus dan balok. Soal tes kemampuan pemecahan masalah matematika sebelum digunakan dilakukan analisis data uji coba instrumen yang meliputi uji validitas, uji reliabilitas, daya pembeda, dan tingkat kesukaran.

Data awal diperoleh dari nilai ulangan harian mata pelajaran matematika siswa kelas VIII tahun pelajaran 2016/2017. Analisis data awal meliputi uji normalitas, uji homogenitas, dan uji kesamaan rata-rata. Analisis data akhir meliputi uji normalitas, uji homogenitas, uji ketuntasan klasikal, dan uji beda rata-rata.

\section{Hasil dan Pembahasan}

Wawancara terhadap salah satu guru matematika kelas VIII di SMP Negeri 5 Batang merupakan kegiatan awal yang dilakukan untuk mengidentifikasi permasalahan-permasalahan yang dihadapi dalam pembelajaran matematika. Hasil dari wawancara tersebut menunjukkan bahwa kompetensi awal siswa untuk mengikuti pembelajaran kurang memadai. Selain itu, siswa terbiasa diajar dengan menggunakan pembelajaran ekspositori yang merupakan suatu pembelajaran yang berorientasi kepada pendidik, sehingga siswa menjadi kurang aktif dalam mengikuti pembelajaran matematika. Pembelajaran tersebut berlangsung secara terus menerus sehingga belum terdapat unsur inovatif dalam pelaksanaan pembelajaran. Akibatnya, pembelajaran tersebut belum mampu mengembangkan kemampuan kognitif, afektif, dan psikomotorik siswa [6, hal. 191]. Dengan demikian, tingkat kemampuan pemecahan masalah matematika siswa cenderung rendah, sehingga mengakibatkan tingkat pencapaian KKM siswa juga rendah. Oleh karena itu, diterapkan model pembelajaran MMP dipadu dengan strategi SSCS agar lebih efektif untuk mengembangkan kemampuan pemecahan masalah matematika siswa dibandingkan dengan strategi pembelajaran ekspositori

Kegiatan selanjutnya yang dilakukan yaitu menentukan populasi penelitian. Populasi dalam penelitian ini adalah seluruh siswa kelas VIII SMP Negeri 5 Batang tahun pelajaran 2016/2017. Berdasarkan populasi yang telah ditentukan, selanjutnya dipilih dua kelas sampel, dengan satu sampel dijadikan sebagai kelompok eksperimen sedangkan satu sampel lainnya digunakan sebagai kelompok kontrol. Pemilihan kelas sebagai kelas sampel dilakukan dengan menggunakan teknik cluster random sampling yaitu dengan memilih 2 kelas secara acak dari 7 kelas yang ada. Berdasarkan acak kelas tersebut, sampel yang terpilih yaitu kelas VIII A sebagai kelas eksper- 
imen dan kelas VIII D sebagai kelas kontrrol. Selain itu, dipilih juga 1 kelas untuk dijadikan sebagai kelas uji coba. Kelas yang terpilih sebagai kelas uji coba yaitu kelas VIII C.

Dilakukan pula pengambilan data nilai kompetensi pengetahuan matematika kedua kelas sampel sebagai data awal penelitian, yaitu berupa data nilai ulangan harian siswa kelas sampel. Dari data awal yang telah diperoleh, kemudian data tersebut dianalisis dengan menggunakaan uji normalitas, uji homogenitas, dan uji kesamaan dua rata-rata.

Uji normalitas data dimaksudkan untuk memperlihatkan bahwa data sampel berasal dari populasi yang berdistribusi normal atau tidak. Pada penelitian ini, pengujian normalitas data menggunakan uji Chi Kuadrat. Uji homogenitas dimaksudkan untuk memperlihatkan bahwa dua atau lebih kelompok data sampel berasal dari populasi yang memiliki variansi yang sama [7, hal. 77]. Untuk keperluan uji homogenitas data akan digunakan pengujian kesamaan varians untuk dua populasi. Uji kesamaan rata-rata (uji t dua pihak). digunakan untuk mengetahui nilai rata-rata siswa pada kedua sampel kelas sama atau tidak. Berdasarkan hasil analisis data awal menunjukkan bahwa kedua kelas sampel berasal dari populasi yang berdistribusi normal, varians kedua kelas homogen, dan rata-rata nilai ulangan harian siswa kelas eksperimen sama dengan rata-rata nilai ulangan harian siswa kelas kontrol, artinya tidak terdapat perbedaan ratarata pada kedua kelas tersebut, sehingga kedua kelas tersebut memiliki kemampuan awal yang sama. Hasil perhitungan disajikan pada Tabel 2 berikut.

Tabel 2. Uji Statistik Data Awal

\begin{tabular}{|c|c|c|}
\hline Uji Statistik & Perhitungan & Simpulan \\
\hline Normalitas & $\chi^{2}<\chi_{\text {table }}^{2}$ & $\begin{array}{c}\text { Kedua kelas sampel berasal dari populasi yang } \\
\text { berdistribusi normal }\end{array}$ \\
\hline Homogenitas & $F \leq F_{\frac{1}{2} \alpha\left(v_{1}, v_{2}\right)}$ & Varians kedua kelas sampel homogen \\
\hline $\begin{array}{l}\text { Kesamaan Dua } \\
\text { Rata-Rata }\end{array}$ & $-t_{\text {tabel }}<t<t_{\text {tabel }}$ & $\begin{array}{c}\text { Kemampuan awal siswa pada kedua kelas sampel } \\
\text { sama }\end{array}$ \\
\hline
\end{tabular}

Kegiatan lain yang dilakukan yaitu menyusun instrumen tes kemampuan pemecahan masalah. Selanjutnya, melaksanakan pembelajaran matematika dengan menerapkan model pembelajaran MMP dipadu dengan strategi SSCS pada kelas eksperimen dan strategi pembelajaran ekspositori pada kelas kontrol.

Pembelajaran pada kelas eksperimen menggunakan model pembelajaran MMP dipadu dengan strategi SSCS diawali dengan guru meninjau ulang pelajaran lalu dan bersama dengan siswa membahas PR yang ada, dilanjutkan dengan guru menyampaikan materi pembelajaran mengenai Kubus dan Balok. Kemudian siswa membentuk kelompok, guru membagikan lembar kerja kelompok, siswa secara berkelompok mengerjakan latihan soal yang terdapat pada lembar kerja kelompok di bawah bimbingan guru dan mempresentasikan hasil pekerjaan kelompoknnya. Selanjutnya guru membagikan lembar kerja individu untuk dikerjakan siswa secara mandiri. Pada akhir pembelajaran, siswa membuat rangkuman pelajaran dilanjutkan dengan guru memberikan PR kepada siswa.

Pembelajaran yang dilaksanakan pada kelas kontrol adalah dengan strategi pembelajaran ekspositori. Pada strategi pembelajaran ekspositori ini, guru memegang peran yang sangat dominan, sebab kegiatan pembelajaran hanya berpusat pada guru sebagai pemberi informasi atau materi pembelajaran, sedangkan siswa cenderung pasif karena hanya memperhatikan guru menjelaskan materi pembelajaran, mencatat materi yang dijelaskan guru, dan dilanjutkan dengan mengerjakan latihan soal yang diberikan guru, sehingga tidak terjadi hubungan timbal balik antara guru dan siswa yang mengakibatkan guru tidak dapat mengetahui tingkat pemahaman siswa berkaitan dengan materi yang telah disampaikan dan soal kemampuan pemecahan 
masalah yang diberikan.

Selama proses melaksanakan pembelajaran baik di kelas eksperimen maupun kelas kontrol, di lain pihak dilakukan pula uji coba instrumen tes kemampuan pemecahan masalah pada kelas uji coba yaitu kelas VIII C. Berdasarkan analisis uji coba tes kemampuan pemecahan masalah, diperoleh hasil bahwa butir soal no 1 s.d. 8 memenuhi kriteria valid, reliabel, mempunyai daya pembeda yang baik dan sangat baik, serta mempunyai tingkat kesukaran yang sedang. Oleh karena itu, seluruh butir soal tersebut digunakan dalam posttest kemampuan pemecahan masalah.

Selanjutnya, kedua kelas sampel diberikan posttest kemampuan pemecahan masalah matematis pada materi Kubus dan Balok. Nilai posttest kemampuan pemecahan masalah matematis pada materi Kubus dan Balok digunakan sebagai data akhir untuk dilakukan analisis uji prasyarat yakni uji normalitas dan homogenitas. Setelah uji prasyarat terpenuhi, maka langkah selanjutnya adalah melakukan uji hipotesis dengan uji ketuntasan klasikal menggunakan uji proporsi satu pihak untuk mengetahui apakah kelas eksperimen mencapai ketuntasan klasikal, dan uji beda rata-rata menggunakan uji pihak kanan dengan rumus uji t untuk mengetahui apakah terdapat perbedaan kemampuan pemecahan masalah matematis siswa antara kelas eksperimen dan kelas kontrol.

Berdasarkan hasil analisis data akhir berkaitan dengan nilai posttest siswa, proporsi nilai siswa pada kelas eksperimen dengan kemampuan pemecahan masalah $\geq 70$ lebih dari $75 \%$. Artinya, siswa pada kelas eksperimen secara klasikal mencapai ketuntasan. Hasil analisis data akhir dengan uji beda rata-rata menunjukkan adanya perbedaan rata-rata kemampuan pemecahan masalah matematika antara siswa yang diajar dengan model pembelajaran MMP dipadu dengan strategi SSCS, dan siswa yang diajar dengan strategi pembelajaran ekspositori. Perbedaan tersebut menunjukkan bahwa rata-rata kemampuan pemecahan masalah siswa kelas eksperimen lebih dari rata-rata kemampuan pemecahan masalah siswa kelas kontrol. Hasil analisis data akhir dapat dilihat pada Tabel 3 berikut.

Tabel 3. Uji Statistik Data Akhir

\begin{tabular}{ccc}
\hline Uji Statistik & Perhitungan & Simpulan \\
\hline Normalitas & $\chi^{2}<\chi_{\text {table }}^{2}$ & Kedua kelas sampel berasal dari populasi yang \\
berdistribusi normal
\end{tabular}

Rata-rata nilai hasil posttest kemampuan pemecahan masalah siswa dapat dilihat pada Tabel 4 berikut.

Tabel 4. Rata-Rata Nilai Post test

\begin{tabular}{ccc}
\hline Kelas & Banyak Siswa & Rata-Rata \\
\hline Kelas eksperimen & 35 & 82.40 \\
Kelas kontol & 35 & 74.30 \\
\hline
\end{tabular}


Hasil penelitian yang demikian diperoleh karena pada setiap pertemuan, siswa di kelas eksperimen diberikan lembar kerja baik individu maupun kelompok yang berisi latihan-latihan soal yang diberikan dari awal hingga akhir pembelajaran dengan soal-soal yang bervariasi sehingga dapat membatu dalam mengasah kemampuan pemecahan masalah matematis siswa. Hal ini sesuai dengan teori belajar dari Gagne yang menyatakan bahwa keterampilan intelektual yang tinggi dapat diperoleh dengan meningkatkan latihan yang diperoleh individu [8, hal. 46].

\section{Kesimpulan dan Saran}

Berdasarkan hasil penelitian, dapat disimpulkan bahwa penerapan model pembelajaran MMP dipadu dengan strategi SSCS mencapai kriteria efektif terhadap kemampuan pemecahan masalah siswa materi kubus dan balok, yang ditandai: (1) kemampuan pemecahan masalah siswa kelas VIII yang diajar dengan menggunakan model pembelajaran MMP dipadu dengan strategi SSCS pada materi Kubus dan Balok dapat mencapai ketuntasan; (2) kemampuan pemecahan masalah antara siswa kelas VIII yang diajar dengan menggunakan model pembelajaran MMP dipadu dengan strategi SSCS lebih baik dari kemampuan pemecahan masalah siswa kelas VIII yang diajar dengan menggunakan strategi pembelajaran ekspositori pada materi Kubus dan Balok.

\section{Pustaka}

[1] B. Maunah, Landasan Pendidikan, Teras, 2009.

[2] Depdiknas, Peraturan Menteri Pendidikan Nasional RI No. 22 Tahun 2006 tentang Standar Isi Kurikulum Pendidikan Dasar dan Menengah, Depdiknas, Jakarta, 2006.

[3] N. Faroh, Sukestiyarno, I. Junaedi, Model missouri mathematics project terpadu dengan TIK untuk meningkatkan pemecahan masalah dan kemandirian belajar. Unnes Journal of Mathematics Education Research 3 (2).

URL https://journal.unnes.ac.id/sju/index.php/ujmer/article/view/4625

[4] E. P. Artawan, I. G. N. Japa, I. W. Widiana, Pengaruh model pembelajaran SSCS terhadap kemampuan pemecahan masalah matematika, Mimb. PGSD 2 (1). URL https://ejournal.undiksha.ac.id/index.php/JJPGSD/article/view/2045

[5] K. E. Lestari, M. R. Yudhanegara, Penelitian Pendidikan Matematika, PT. Refika Aditama, 2015.

[6] W. Sanjaya, Strategi Pembelajaran Berorientasi Standar Proses Pendidikan, Kencana, 2013.

[7] M. A. Gunawan, Statistik Penelitian Bidang Pendidikan, Psikologi dan Sosial, Parama Publishing, 2015.

[8] Aunurrahman, Belajar dan Pembelajaran, Alfabeta, Bandung, 2010. 